\title{
Parents Do These Things
}

Tziporah Rosenberg, PhD

(Fam Med. 2021;53(4):307-8.)

doi: 10.22454/FamMed.2021.831377

$\mathbf{T}$ oday I revised my living will. I'm young-ish. I'm mostly healthy. I eat decently most of the time, and always have fresh fruits and veggies in my fridge. Admittedly I don't always eat them. I work out regularly... intermittently. When I'm not regular about it, I think lots about how to get back to it, and eventually do just that. My 39 years with type 1 diabetes have seen me taking pretty good care of it, and I'm an engaged, active agent of my own health care.

I executed a living will once in my life, within months of my daughter being born almost 10 years ago. I thought, "Hey, never too early to make some things clear. Besides, now I'm a mother, and parents do these things." It seemed a big deal at the time, replete with talking to my family about what I would want for myself and my treatment should I become incapacitated. I asked my mother for a template, some guidance, and eventually feedback. I reflected deeply. I approached conversations with my siblings directly but gently. I looked at my baby and dreaded even mentally visiting the possibility that I'd ever leave her. I cried, several times. I signed it with my attorney and filed it away for such time as I might need it; I hoped so much that I'd not need it that I filed it someplace where I now cannot find it.
Our medical center's teams are all entering week 4 of our own close-up experiences of the COVID-19 pandemic. Colleagues and friends are posting articles about unthinkably difficult end-of-life decisions: vent allocation, so many uncertainties, bedside phone calls to family who can't visit. All of them make me certain amidst uncertainty: I want to make clear my wishes well in advance of any of that. I want my own family to know now, just in case. I want my own family to do what they can to act on my wishes should that time come for me. I want it all to be clear. I don't want them to wonder or fill in the blanks about what is most important to me, even if it's hard.

I am the sixth of seven children, and grew up with two lawyer parents. Holiday dinner table conversations were always full of wry quips, thoughtful and lengthy arguments, and terrible puns... still are, really. I am fastidious about my research. I believe in my own agency, and seek to promote the same in others. I can write a formidable business letter with plenty of big words and legalese if necessary. And I do my best in my life to talk about hard things matter-of-factly. I'm a medical family therapist and a medical educator. I teach about the importance of genograms and am ever reflecting on my own, which, in a family as dynamic as mine, is indeed its own unpaid but valuable work. I spend my days training health professionals from all disciplines around all things humanistic, patient-centered, communication, and behavioral health. I am not a stranger to hard conversations about hard things, nor the complexity of our roles in our families. I got a degree in those. I'm still paying the loans on it.

I have watched, with an unsettled feeling in my stomach, as the viral infection spreads across our country, my state, my town in my county. I work in our city's largest medical center, and have been privy to the COVID Command Center updates here and there. We are prepared for catastrophe, the worst-case scenarios. We still hope they never come.

So I decided this weekend to update my living will (read: write a new one, because who the heck knows where my initial one is anymore?). I did my research. I googled. I talked with professionals about what we know, and all we don't, about the stuff that matters in an advanced care directive. I created a document that I feel pretty proud of. It's comprehensive, outlines some contingencies related to COVID-19 and vent shortages, and makes it clear what I want, and until when. As I do with any formal letter or legal-ish document, I asked my lawyer mother to

From the University of Rochester School of Medicine - Family Medicine, Rochester, NY. 
review it. Naturally she agreed. I attached it to an email where her address is comprised of her name, but in my contacts list simply reads "Mama."

An hour later I checked my email expecting a revision with red ink, or whatever the electronic equivalent might be. Instead, her reply: "Call when you have time to discuss." Nervously, I dialed her back.

My lawyer mother started the conversation with feedback about the text, my verbiage, places where the document needed clarification, or to fix a typo. It felt at once familiar, and also... different. Grown up. Serious. Suddenly she tearfully muttered, "I just don't know what I'd do if anything ever happened to one of you kids. I can't even think about it."

Reflexively, I quipped, "Well don't think about it then."

"Don't think about it then"? Who was that? Not the doctorally-prepared family therapist. Not the faculty person in a busy residency program who heads up psychosocial medicine training for family medicine physicians. It was my mother's daughter. I could never stand seeing her sad or scared. It made my heart hurt. And it made me sad and scared, too. I let go of the breath I realized I'd been holding.
“Mama, I know you don't. I don't either. And I don't know what we'd do if anything ever happened to you." "Yeah, but I'm 85."

"Yeah, but we have only one of you. And you are irreplaceable."

Mother. Daughter. We were quiet for a few seconds. Maybe mothers shouldn't have to think about losing their daughters.

"Ok, so on page 5..." she continued, and, dutifully, I sat down to record the edits she recommended, just like we'd done countless times before. "Thank you, Mama. Was this ok for you?" I wasn't entirely sure that it was ok for me. I wondered how my wish to be direct and matter of fact seemed to miss how hard it was for either of us to contemplate losing each other.

"Not really, but... make sure you have plenty of signed originals, so you can get all the other signatures... and don't forget to make a line to add the date." Got it. Right. She left no detail unattended. I wondered who helped her with hers when she wrote it. I should ask her sometime.

Before I can wrap up the call, I attune myself to yet another voice, "Mama! Come outside and see what I can do!" My spritely almost 10-year old summoned me, inviting me to bear witness to her newfound skills in bubble-catching using a toy that the era of shelter-in-place allowed us the time and space to discover. I have learned during these weeks to make room. Be flexible. Leave things undone sometimes because the present, her present, needs me to be in it. I returned briefly to the call, promised to incorporate my mother's edits and send them back for one last review. She swallowed back tears as we said goodbye.

Parents do these things, even if we don't always want to.

CORRESPONDENCE: Address Correspondence to Dr Tziporah Rosenberg, University of Rochester School of Medicine - Family Medicine, 777 S Clinton Ave, Rochester NY 14620. Tziporah_Rosenberg@urmc.rochester.edu. 